\title{
UPAYA PENDIDIKAN KELUARGA DALAM MENANGGULANGI KENAKALAN REMAJA DI DESA DAUN SANGKAPURA BAWEAN GRESIK
}

\author{
Ansharuddin M \\ STAI Hasan Jufri Bawean \\ anshar_ruddin@yahoo.com
}

\begin{abstract}
This article will discuss family education and family efforts to overcome juvenile delinquency. The family as the first and foremost educator for children is obligatory to educate children to be good. The rise of the phenomenon of juvenile delinquency is increasingly troubling the public, especially in the era of globalization and technology and in the middle of school politics which increasingly corners the existence of family education. For this reason, this study seeks to uncover and analyze the forms of juvenile delinquency and how the family's efforts in overcoming juvenile delinquency are increasingly prevalent, especially in the midst of the Bawean people who are 100\% Muslim. Therefore, the existence of this research can later be used as input for all families to look after and care for their children as well as possible so that they can become good children.
\end{abstract}

Keywords: Education, Family, Delinquency, Adolescent

\begin{abstract}
Abstrak: Artikel ini akan membahas tentang pendidikan keluarga dan upaya keluarga dalam menanggulangi kenakalan remaja. Keluarga sebagai pendidik pertama dan utama bagi anak wajib hukumnya untuk mendidik anak agar menjadi baik. Maraknya fenomena kenakalan remaja kian meresahkan masyarakat terutama di era globalisasi dan teknologi serta di tengah politik sekolah yang semakin menyudutkan eksistensi pendidikan keluarga. Untuk itu, dalam penelitian ini berusaha untuk mengungkap dan menganalisa bentuk-bentuk kenakalan remaja serta bagaimana upaya keluarga dalam menanggulangi kenakalan remaja yang kian marak, khususnya di tengah-tengah masyarakat Bawean yang berpendudukan 100\% Islam. Karenanya, dengan adanya penelitian ini nantinya dapat digunakan sebagai masukan bagi semua keluarga untuk menjaga dan memperhatikan anaknya sebaik mungkin sehingga bisa menjadi anak yang baik.
\end{abstract}

Kata kunci: Pendidikan, Keluarga, Kenakalan, Remaja

\section{Pendahuluan}

Pendidikan merupakan kebutuhan utama untuk kemajuan manusia. Oleh karena itu, Islam memberikan perhatian khusus pada masalah tersebut. Islam mensyariatkan pendidikan tidak hanya menghasilkan manusia-manusia yang cerdas 
akal, tapi juga manusia yang berbudi luhur. Keluarga ${ }^{1}$ sebagai otoritas pertama dan utama dalam membentuk pendidikan anak harus mampu menjalankan fungsinya semaksimal mungkin sehingga output yang dihasilkannya bisa maksimal.

Berkenaan dengan pendidikan, dalam kutipan Zakia Daradjat, dikatakan "pendidikan berlangsung seumur hidup dan dilaksanakan di dalam rumah tangga, sekolah dan masyarakat. Karena itu pendidikan adalah merupakan tanggung jawab bersama antara keluarga, masyarakat dan pemerintah". ${ }^{2}$ Hal ini menjadi sangat menarik karena posisi keluarga ditempatkan pada urutan pertama dari terlaksananya pendidikan seumur hidup. Tentu sangat rasional karena mengingat waktu anak lebih banyak bersama keluarga dari pada di sekolah.

Pembentukan identitas anak menurut Islam, dimulai jauh sebelum anak diciptakan. Islam memberikan berbagai syarat dan ketentuan pembentukan keluarga, sebagai wadah yang akan mendidik anak sampai umur tertentu yang disebut balighberakal. ${ }^{3}$ Lebih lanjut Rehani memaparkan, "keluarga adalah wadah pertama dan utama bagi pertumbuhan dan perkembangan anak. Jika suasana dalam keluarga itu baik dan menyenangkan, maka anak akan tumbuh dengan baik pula. Jika tidak, tentu akan terhambatlah pertumbuhan anak tersebut."

Rehani menjelaskan, "sejalan dengan semakin pesatnya arus globalisasi dan demikian canggihnya dunia ilmu pengetahuan dan teknologi ternyata dari satu sisi memunculkan persoalan-persoalan baru yang kerap kita temukan pada diri individu dalam suatu masyarakat." ${ }^{5}$ Oleh karena itu, dibutuhkan adanya bimbingan dari pihakpihak terkait (keluarga, sekolah, dan masyarakat) serta adanya kesadaran pada diri individu untuk memfilter hal-hal negatif yang akan mempengaruhi dirinya. Dengan begitu, kekhawatiran orang tua terhadap dampak negatif dari arus globalisasi dan kemajuan teknologi tidak akan terjadi pada anak.

Menurut Hamka, sebagaimana dalam kutipan Samsul Nizar ada dua bentuk kewajiban kedua orang tua terhadap anak. Kewajiban tersebut adalah; Pertama, kewajiban memelihara lahiriah yang meliputi menjaga kesehatan, makan dan minum yang halal hala al-thayyibat, serta kebutuhan fisik lainnya. Kedua, kewajiban memelihara batiniah yang meliputi kenyamanan dan ketenteraman, serta pendidikan sebagai persiapan untuk kehidupannya di belakang hari. ${ }^{6}$

Berdasarkan penjelasan di atas bahwa pendidikan memiliki peran yang sangat penting dalam kehidupan manusia. Jika hal ini dikaitkan dengan pendidikan keluarga

\footnotetext{
${ }^{1}$ Keluarga dalam kamus besar bahasa Indonesia berarti, ibu dan bapak, beserta anak-anaknya, seisi rumah, serta orang seisi rumah yang menjadi tanggungan. Lihat Tim Penyusun Kamus, Kamus Besar Bahasa Indonesia, 232.

2 Zakiah Daradjat, et.al., Ilmu Pendidikan Islam (Jakarta: Bumi Aksara, 1996), 34.

${ }^{3}$ Zakiah Daradjat, Pendidikan Islam dalam Keluarga dan Sekolab (Jakarta: Ruhama, 1995), 41.

${ }^{4}$ Ibid., 47.

${ }^{5}$ Rehani, Berawal dari Keluarga: Revolusi Belajar Cara al-Qur'an (Jakarta: Hikmah, 2003), XI.

${ }^{6}$ Samsul Nizar, Memperbincangkan Dinamika Intelektual dan Pemikiran Hamka Tentang Pendidikan Islam (Jakarta: Kencana, 2008), 139.
} 
maka keluarga merupakan benteng pertama dan utama dalam membendung dampak dari globalisasi sehingga terbentuk pribadi muslim sejati. ${ }^{7}$

Keluarga merupakan orang yang terdekat dengan anak tentu mereka lebih mengerti apa yang dibutuhkan anak. Terutama kedua orang tua yang telah menjaga dan merawat anak mulai dari dalam kandungan sampai ia besar dan tumbuh menjadi dewasa.

Namun seiring berkembangnya zaman, sering kali orang tua lupa terhadap kewajibannya bahwa anak adalah titipan Tuhan yang harus ia jaga sedemikian rupa sehingga menjadi anak yang bermanfaat bagi dirinya dan orang lain. Banyak diantara mereka yang belum mengerti apa dan bagaimana seharusnya memperlakukan anak dengan baik, agar anak tidak terjerumus dalam pergaulan bebas serta berbagai jenis kenakalan remaja lainnya.

Mengenai jenis kenakalan remaja yang dikumpulkan oleh pemerintah melalui Bakolak Impres 6/1971 dalam kutipan Sofyan S. Willis, yaitu: 1). Pencurian, 2). Penipuan, 3). Perkelahian,4). Perusakan, 5). Penganiayaan, 6). Perampokan, 7). Narkotika, 8). Pelanggaran susila, 9). Pelanggaran, 10). Pembunuhan, dan 11). Kejahatan lain. ${ }^{8}$

Beberapa bentuk kenakalan remaja yang dikemukakan di atas terjadi pada remaja di Bawean seperti; pencurian, perkelahian, perusakan, narkotika, bahkan barubaru ini terjadi pemerkosaan antar pelajar, sebagaimana dilansir oleh Media Bawean yang terjadi pada tanggal 1 Januari 2016. ${ }^{9}$ Ini seharusnya mendapat perhatian yang serius dari pihak-pihak terkait terutama kedua orang tua sebagai benteng utama dan pertama dalam pembentukan sikap anak. Karena memang selama ini khususnya di Bawean kurang mendapatkan perhatian yang serius dari masyarakat dan aparat berwajib.

Kenakalan remaja kian meresahkan masyarakat. Hal ini tidak bisa di katakan bahwa yang di lakukan adalah murni karena keinginan mereka sendiri, bisa jadi kenakalan yang mereka lakukan adalah merupakan pengaruh dari lingkungan anak atau sebagai bentuk protes anak untuk menunjukkan eksistensi mereka kepada orang tua ataupun masyarakat yang sudah tidak berlaku adil pada dirinya.

Di era persekolahan formal, peran orang tua semakin dipertanyakan. Waktu anak di habiskan di sekolah untuk menerima pelajaran-pelajaran sekolah yang sangat menguras tenaga dan membosankan. Karena dominasi sekolah pula banyak orang tua kehilangan kepercayaan diri untuk mendidik anak-anaknya, lalu kehilangan harga diri

\footnotetext{
${ }^{7}$ Seseorang disebut memiliki kepribadian muslim manakala ia dalam mempersepsikan sesuatu, dalam bersikap terhadap sesuatu dan dalam melakukan sesuatu dikendalikan oleh pandangan hidup muslim. Achamd Mubarok, Psikologi Keluarga: Dari Keluarga Sakinah Hingga Keluarga Bangsa (Jakarta: Wahana Aksara Prima, 2009), 46.

8 Sofyan S. Willis, Remaja dan Masalabnya: Mengupas Berbagai Bentuk Kenakalan Remaja, Narkotika, Sex, dan Pemecabannya (Bandung: Alfabeta, 2012), 91.

9 "Tidak Hanya Dipaksa Hubungan Intim hingga 25 Kali, Bunga juga Diperas", http://www.bawean.net/2016/02/tidak-hanya-dipaksa-hubungan-intim.html, diakses tanggal 11 Februari 2016.
} 
jika anak-anaknya tidak bersekolah. Ditambah dengan keadaan sekolah/lembaga pendidikan yang akhir-akhir ini marak dibicarakan di berbagai media, seperti kasus pemerkosaan, guru killer, tawuran antar pelajar, seks bebas, narkoba, miras, dan sederet catatan hitam lainnya. Sekolah tidak lagi memberikan lingkungan yang nyaman, aman dan kondusif bagi anak. Dalam bahasa Ivan Illich, "sekolah membuat mereka tak mampu membedakan proses dari substansi." ${ }^{\prime \prime}$ Di sinilah peran penting pendidikan keluarga sebagai benteng utama untuk membebaskan anak dari berbagai ancaman dan memberikan rasa aman bagi anak.

Sejauh yang penulis tahu, masyarakat Bawean sampai saat ini adalah masyarakat yang fanatik terhadap agama, terutama terhadap paham Ahlus Sunnah Wal-Jamaah, bahkan penduduknya 100\% beragama Islam. ${ }^{11}$ Jadi tidak heran jika di Bawean banyak kegiatan-kegiatan keagamaan seperti pengajian rutin, memperingati hari-hari besar Islam dan lain sebagainya yang dirayakan secara besar-besaran dan mungkin tidak dijumpai di daerah lain seperti contoh perayaan maulid Nabi Muhammad Saw, Isra' Mi'raj dan lain-lain.

Pulau Bawean bisa dikatakan juga Pulau Santri, bagaimana tidak Bawean yang hanya terdiri dari dua kecamatan ternyata terdapat banyak pondok pesantren, tidak heran jika masyarakat di Bawean secara kualitas pengetahuan mereka terhadap agama bisa di bilang baik. Terlebih lagi hampir semua penduduk di Bawean pernah mengenyam pendidikan agama di berbagai pondok pesantren baik di Bawean maupun di luar Pulau Bawean. Ini menjadi nilai lebih bagi masyarakat Bawean.

Namun, keberadaan umat Islam di Bawean yang secara kualitas sudah baik ternyata tidak mampu membendung adanya kenakalan remaja yang terjadi di Pulau Bawean. Hemat penulis, seharusnya ketika masyarakat itu adalah orang-orang yang taat beragama bisa dipastikan dapat membendung adanya kenakalan remaja yang terjadi di sekitarnya, alih-alih mereka berdalih, dimana terdapat banyak ulama di situ pasti banyak kemungkaran, argumen yang seperti ini bagi penulis bukanlah sebuah alasan melainkan sebuah apologi dari ketidakberdayaan para orang tua dan tokoh agama serta lembaga-lembaga yang bertanggung jawab dalam membentuk moralitas remaja untuk membendung fenomena kenakalan remaja di sekitarnya.

Di satu sisi, masyarakat Bawean selain masyarakat yang kental dengan kegiatan keagamaan adalah masyarakat pesisir yang mayoritas penduduknya bekerja

\footnotetext{
${ }^{10}$ Ivan Illich mengatakan, begitu kedua hal ini proses dan substansi dicampur adukkan, muncul logika baru: semakin banyak pengajaran semakin baik hasilnya; atau, menambah materi pengetahuan akan menjamin keberhasilan . Akibatnya, murid menyamakan begitu saja pengajaran dengan belajar, naik kelas dengan pendidikan, ijazah dengan kemampuan, dan kefasihan berceloteh dengan kemampuan mengungkapkan sesuatu yang baru. Anak dibiasakan menerima pelayanan, bukannya nilai. Lihat, Ivan Illich, Bebaskan Masyarakat dari Belenggu Sekolah. Terj. Sonny Keraf (Jakarta: Yayasan Obor Indonesia, 2000), 1.

11 Perlu dibedakan di sini adalah antara masyarakat Islam dengan masyarakat Islami karena terkadang sebagian orang menganggap antara keduanya sama saja. Mengutip pendapat Ahmad Mubarok, menyatakan masyarakat Islam adalah kumpulan masyarakat yang beragama Islam, sedangkan masyarakat Islami adalah masyarakat yang di dalamnya berlaku nilai-nilai Islam. Achamd Mubarok, Psikologi Keluarga, 243.
} 
sebagai Tenaga Kerja Indonesia (TKI) di luar pulau Bawean seperti Malaysia, Singapura, dan lain-lain, atau memilih kerja di Pelayaran. Bukan hal yang mudah memilih di antara pekerjaan tersebut namun sudah menjadi semacam tuntutan bagi mereka terutama masyarakat Bawean sebagai masyarakat pesisir.

Kondisi ini menjadikan orang tua serba dilematis, di satu sisi mereka harus bekerja untuk mencari nafkah keluarga namun di sisi lain mereka berkewajiban untuk mendidik anak. Sehingga mau tidak mau anaklah yang menjadi korbannya. Bukan suatu hal yang tabu jika ada anak yang masih duduk di bangku TK, SD atau bahkan SMP/SMA sudah ditinggal (kerja di luar negeri) dalam kurun waktu yang cukup lama, jika sudah seperti ini bukankah secara psikologis mereka sudah kehilangan orang tua mereka sebelum mereka benar-benar kehilangannya.

Berdasarkan konteks di atas penelitian ini dirasa penting dan perlu untuk mengetahui bagaimana bentuk kenakalan remaja dan upaya yang dilakukan keluarga dalam menanggulangi masalah kenakalan remaja khususnya di desa Daun dan masyarakat luas pada umumnya.

\section{Pendidikan dan Keluarga}

1. Pendidikan

Pendidikan, menurut Kamus Besar Bahasa Indonesia, berarti "proses pengubahan sikap dan tata laku seseorang atau kelompok orang dalam usaha mendewasakan manusia melalui upaya pengajaran dan pelatihan."12 Sebagaimana dijelaskan Ali Anwar, "Pendidikan secara etimologis juga berarti proses, perbuatan, cara mendidik.",13

Pendidikan dalam UU SISDIKNAS (Sistem Pendidikan Nasional) memiliki pengertian sebagai berikut:

Pendidikan adalah usaha sadar dan terencana untuk mewujudkan suasana belajar dan proses pembelajaran agar peserta didik secara aktif mengembangkan potensi dirinya untuk memiliki kekuatan spiritual keagamaan, pengendalian diri, kepribadian, kecerdasan, akhlak mulia, serta keterampilan yang diperlukan dirinya, masyarakat, bangsa dan negara. $^{14}$

Penentuan kata yang sepadan dengan pendidikan telah diperdebatkan oleh para ahli. Di antara mereka ada yang konsisten dengan term tarbiyah, tetapi yang lainnya justru konsisten dengan term lain, seperti ta'dib atau ta'lim dan lain sebagainya. ${ }^{15}$ Kata pendidikan (tarbiyah) menurut Suaid, dalam kutipan Zeni Luthfiah "memiliki tiga kata dasar yaitu: dari kata rabaa-yarbuu (bertambah dan

12 Tim Penyusun Kamus, Kamus Besar Bahasa Indonesia, Edisi Keempat (Jakarta: Gramedia, 2000), 232.

${ }^{13}$ Ali Anwar, Pembaruan Pendidikan Di Pesantren Lirboyo Kediri (Yogyakarta: Pustaka Pelajar, 2011), 20.

${ }^{14}$ Undang-Undang Sisdiknas Sistem Pendidikan Nasional (t.t.: Permata Pres, t.t. ), 2-3.

15 Moljono Damopoli, Pesantren Modern IMMIM Pencetak Muslim Modern (Jakarta: Rajagrafindo Persada, 2011), 42. 
berkembang), rabaa-yarbii (tumbuh dan mekar), rabba-yarubbu (memperbaiki dan mengurus suatu perkara)." ${ }^{\prime 16}$

Terlepas dari seberapa jauh ketepatan argumen Naquib Al-attas mengenai penggunaan istilah ta'dib bagi pendidikan Islam, dalam pembahasan ini tidak ingin diperdebatkan karena sesungguhnya ketiga istilah tersebut (tarbiyah, ta'lim dan ta'dib) merupakan satu kesatuan yang saling terkait. Artinya, apabila pendidikan dinisbatkan kepada ta'dibiah harus melalui pengajaran (ta'lim) sehingga dengannya diperoleh Ilmu. Agar Ilmu dapat dipahami, dihayati, dan selanjutnya di amalkan oleh peserta didik perlu bimbingan (tarbiyab). ${ }^{17}$

Pengertian lainnya yang lebih bersifat sederhana dan umum dikemukakan oleh M. Djumransjah, dalam kutipan Moljono Damopolii memaknai pendidikan sebagai "usaha manusia untuk menumbuhkan dan mengembangkan potensipotensi bawaan, baik jasmani maupun rohani, sesuai dengan nilai-nilai yang ada dalam masyarakat dan kebudayaan". ${ }^{18}$

Berdasarkan paparan di atas, pendidikan adalah usaha sadar dan terencana untuk mewujudkan suasana belajar dan proses pembelajaran agar peserta didik secara aktif mengembangkan potensi dirinya secara efektif dan efisien untuk mencapai kebahagiaan hidup di dunia dan akhirat.

2. Keluarga

a. Definisi Keluarga

Ditinjau dari aspek kebahasaan, di dalam bahasa Ingris menurut HW Fowler dalam kutipan Mahmud, kata "keluarga" adalah "family" yang berasal dari kata "familier" yang berarti dikenal dengan baik atau terkenal. Selanjutnya kata kata family tidak terbatas pada keluarga manusia saja; akan tetapi membentang dan meluas sehingga meliputi setiap anggotanya untuk saling mengenal. Terkadang pula makna keluarga meluas sehingga ia benar-benar keluarga dalam arti luas, yaitu sekumpulan umat dan negara yang berdekatan. ${ }^{19}$

Sementara itu, menurut Mahmud, kata keluarga dalam bahasa Arab adalah "al-usrah" yang merupakan kata jadian dari "al-asru". Secara etimologis berarti ikatan (al-qa'id). Al-Razi, dalam kutipan Mahmud mengatakan "al-asru" maknanya mengikat dengan tali atau yang lain. ${ }^{20}$ Lebih lanjut Novan Ardy Wiyani \& Barnawi mengatakan, keluarga adalah suatu "lingkungan kecil yang terdiri atas ibu dan bapak beserta anak-anaknya. Komposisi tersebut sering

16 Zeni Luthfiah, et.al., Pendidikan Agama Islam Pendidikan Karakter Berbasis Agama Islam (Surakarta: Yuma Pustaka, 2011), 218. Lihat Pula, Achmadi, Ideologi Pendidikan Islam Paradigma Humanisme Teosentris (Yogyakarta: Pustaka Pelajar, 2005), 25.

${ }^{17}$ Ibid .

${ }_{18}$ Moljono Damopoli, Pesantren Modern, 49.

${ }_{19}$ Mahmud, et.al, Pendidikan Agama Islam dalam Keluarga: Sebuah Panduan Lengkap bagi Para Guru, Orang tua dan Calon (Jakarta: Akademia Permata, 2013), 127-128.

${ }^{20}$ Ibid., 128. 
dinamakan dengan istilah keluarga inti. Keluarga juga berarti orang seisi rumah yang menjadi tanggungan." 21

Berkaitan dengan hal di atas Moh. Haitami Salim, mengatakan keluarga adalah suatu institusi yang terbentuk karena ikatan perkawinan. Di dalamnya hidup bersama pasangan suami istri secara sah karena pernikahan. Keluarga dapat dipahami dari dimensi hubungan darah dan hubungan sosial. Jika dipahami dari dimensi hubungan darah, keluarga merupakan suatu kesatuan yang diikat oleh hubungan darah antara satu dengan lainnya.

Berdasarkan dimensi ini, keluarga bisa dibedakan menjadi keluarga inti dan keluarga besar. Sementara dari dimensi hubungan sosial, keluarga merupakan suatu kesatuan yang di ikat adanya saling berhubungan atau interaksi dan saling mempengaruhi antara satu dengan yang lainnya, walaupun diantara mereka tidak terdapat hubungan darah. ${ }^{22}$

Berdasarkan penjelasan di atas, dapat dipahami keluarga adalah sekelompok individu yang terbentuk oleh adanya hubungan darah atau ikatan pernikahan suami-istri secara sah yang memilih hidup bersama untuk mencapai tujuan yang telah di tentukan.

b. Tujuan Pembentukan Keluarga

Jika dikatakan bahwa keluarga adalah merupakan pilar utama bagi terbentuknya masyarakat dan bangsa yang beradab, tentunya hal itu harus dimulai dari adanya tujuan yang jelas dalam pembentukan keluarga. Hal ini perlu mengingat betapa pentingnya arah dan tujuan dalam keluarga sehingga dengan adanya tujuan yang jelas akan memantapkan setiap langkah dan perilaku dalam suatu keluarga untuk menjadi keluarga bangsa yang berkarakter dan berbudaya yang beradab. Oleh karena itu, dikatakan oleh Moh. Haitami Salim, suatu bangsa akan baik jika masyarakatnya baik, dan suatu masyarakat akan baik jika masingmasing keluarga dapat hidup secara baik pula. Demikian pula, suatu bangsa akan berkarakter kuat jika masyarakatnya memiliki karakter yang kuat. Masyarakat akan berkarakter kuat jika terdiri dari keluarga yang memiliki karakter yang kuat pula. $^{23}$ Karena keluarga merupakan wadah pertama dan utama dalam pembentukan kepribadian dan pendidikan anak maka idealnya keluarga dalam hal ini kedua orang tua memiliki peran yang sangat penting untuk terbentuknya sikap dan perilaku anak yang baik.

Keluarga dalam agama Islam terbentuk melalui ikatan pernikahan serta dijalankan dengan ajaran syari'at dan norma yang berlaku. Pernikahan adalah ikatan yang mulia dan diberkahi. Allah SWT telah mensyari'atkan pernikahan untuk kemaslahatan dan kemanfaatan hamba-hambanya, agar dengannya mereka

${ }^{21}$ Novan Ardy Wiyani \& Barnawi, Ilmu Pendidikan Islam: Rancang Bangun Konsep Pendidikan MonokotomikHolistik (Jogjakarta: Ar-Ruz Media, 2012), 55.

${ }^{22}$ Moh. Haitami Salim, Pendidikan Agama dalam Keluarga: Revitalisasi Peran Keluarga dalam Membangun Generasi Bangsa yang Berkarakter (Jogjakarta: Ar-Ruzz Media, 2013), 75.

${ }^{23}$ Moh. Haitami Salim, Pendidikan Agama dalam Keluarga, 292. 
dapat mencapai maksud-maksud yang baik dan tujuan-tujuan yang mulia. ${ }^{24} \mathrm{Nur}$ Ahid menjelaskan, tujuan dari sebuah pernikahan ada dua, yaitu "memperoleh keturunan dan menjauhi dari keharaman." 25

Berdasarkan penjelasan di atas dapat di pahami bahwa tujuan pembentukan keluarga adalah sebagai wadah untuk melestarikan keturunan demi keberlangsungan kehidupan manusia yang beriman dan bertaqwa kepada Allah SWT. Nurcholish Madjid, mempertegas "tujuan berkeluarga adalah mencapai kualitas hidup sakinah yang berpangkal dari cinta kasih yang tulus antara dua pribadi dari dua jenis". ${ }^{26}$

c. Fungsi Keluarga

Sebagaimana dijelaskan di muka bahwa keluarga merupakan sekelompok individu yang terbentuk oleh adanya ikatan darah maupun perkawinan. Untuk itu, keluarga memiliki beberapa fungsi pokok antara lain: ${ }^{27}$ (1) Fungsi Edukasi (2) Fungsi Proteksi (3) Fungsi Afeksi (4) Fungsi Sosialisasi (5) Fungsi Reproduksi (6) Fungsi Religi (7) Fungsi Ekonomi (8) Fungsi Rekreasi (9) Fungsi Biologis (10) Fungsi Transformasi

Berdasarkan penjelasan di atas, keluarga memiliki fungsi yang sangat kompleks terhadap perkembangan anak agar anak mampu beradaptasi dengan lingkungan sekitarnya. Sri Lestari menambahkan, fungis paling penting dari keluarga adalah melakukan perawatan dan melakukan sosialisasi ${ }^{28}$ pada anak. ${ }^{29}$

\section{Pendidikan dalam Keluarga}

1. Tujuan pendidikan agama dalam keluarga

Secara umum, Dina Mulyanti, dalam kutipan Mahmud mengemukakan "tujuan pendidikan Islam dalam keluarga adalah mendidik dan membina anak menjadi manusia dewasa yang memiliki mentalitas dan moralitas yang luhur bertanggung jawab baik secara moral, agama maupun sosial kemasyarakatan". ${ }^{30}$

Adapun yang bertindak dalam merealisasikan tujuan pendidikan dalam keluarga tersebut menurut Ahmad Tafsir yakni, ayah dan ibu si anak serta semua orang yang merasa bertanggung jawab terhadap perkembangan anak itu seperti kakek, nenek, paman, bibi, dan kakak. Yang paling bertanggung jawab adalah ayah dan ibu. Bila di rumah tidak hanya terdapat ayah dan ibu (ada kakek dan nenek, misalnya), maka kebijakan pendidikan yang dipegang mereka seharusnya

\footnotetext{
${ }^{24}$ Nur Ahid, Pendidikan Keluarga dalam Perspektif Islam (Yogyakarta: Pustaka Pelajar, 2010), 92.

25 Ibid., 92-93.

${ }^{26}$ Nurcholis Madjid, Masyarakat Religius (Jakarta, Paramadina, 2000), 74.

27 Amirulloh, Teori Pendidikan; Karakter Remaja Dalam Keluarga (Bandung: Alfabet, 2015), 49-55.

28 Sosialisasi adalah merupakan proses yang ditempuh anak untuk memperoleh keyakinan, nilai-nilai dan perilaku yang di anggap perlu dan pantas oleh anggota keluarga dewasa, terutama orang tua. Lihat, Sri Lestari, Psikologi Keluarga: Penanaman Nilai dan Penanganan Konflik Dalam Keluaarga (Jakarta: Kencana, 2014), 22.

${ }^{29}$ Ibid.

${ }^{30}$ Mahmud, Pendidikan Agama Islam dalam Keluarga, 155.
} 
satu; tidak boleh terjadi kebijakan yang saling berlawanan. Biasanya kebijakan kakek-nenek sering berbeda dari kebijakan ayah dan ibu. ${ }^{31}$

2. Tanggung jawab orang tua terhadap anak

Pendidikan tidak dapat dipisahkan dari tiga hal, yaitu keluarga, sekolah, dan masyarakat. Keberhasilan pendidikan dalam suatu negara atau daerah tergantung kepada tiga faktor tersebut. ${ }^{32}$ Untuk mencapai keberhasilan tersebut beberapa tanggung jawab orang tua terhadap anak antara lain adalah: a).Tanggung Jawab Pendidikan dan Pembinaan Akidah, b). Tanggung Jawab Pendidikan dan Pembinaan Akhlak, c). Tanggung Jawab Pemeliharaan Kesehatan Anak, d). Tanggung Jawab Pendidikan dan Pembinaan Intelektual, e). Tanggung Jawab Kepribadian dan Sosial Anak.

3. Pola asuh orang tua terhadap anak

Pola asuh maksudnya adalah cara pengasuhan yang diberlakukan oleh orang tua dalam keluarga sebagai perwujudan kasih sayang mereka kepada anakanaknya. Orang tua sebagai pendidik memiliki tanggung jawab yang sangat besar dalam pengasuhan, pembinaan, dan pendidikan, dan ini merupakan tanggung jawab yang primer. ${ }^{33}$

Berkaitan dengan hal di atas, Elizabeth B. Hurlock mengatakan bahwa "sikap orang tua mempengaruhi cara mereka memperlakukan anak, dan perlakuan mereka terhadap anak sebaliknya mempengaruhi sikap anak terhadap mereka dan prilaku mereka. Pada dasarnya hubungan orang tua-anak tergantung pada sikap orang tua." 34

Secara umum, Baumrid dalam kutipan Mahmud, mengategorikan pola asuh menjadi tiga jenis, yaitu: (1) pola asuh authoritarian (otoriter); (2) pola asuh authoritative, dan (3) pola asuh permissive.

Tiga jenis pola asuh Baumrid ini hampir sama dengan jenis pola asuh menurut Hurlock juga Hardy \& Heyes, masih dalam kutipan Mahmud yaitu: (1) pola asuh otoriter, (2) pola asuh demokratis, dan (3) pola asuh permisif. ${ }^{35}$

Berdasarkan paparan di atas, berbagai pola asuhan orang tua terhadap anak menurut hemat penulis tidaklah tepat jika diterapkan dalam keadaan terpisah karena pada hakikatnya antara satu dengan yang lain saling melengkapi, yang paling menentukan manakah yang terbaik di antara ketiganya adalah bergantung pada situasi dan kondisi keluarga tersebut.

\section{Keluarga Sebagai Pilar Utama (Tripusat Pendidikan)}

Keluarga adalah satu-satunya sistem sosial yang diterima di semua masyarakat, baik yang agamis maupun yang nonagamis. Ia memiliki peran, posisi dan kedudukan

31 Ahmad Tafsir, Ilmu Pendidikan Islam (Bandung: Remaja Rosdakarya, 2012), 155.

32 Qadar Muhammad Yusuf, Tafsir Tarbawi (Pekanbaru: Zanafa Publishing, 2011), 187.

33 Ibid., 149-150.

${ }^{34}$ Elizabeth B. Hurlock, Perkembangan Anak terj. Med. Meitasari Tjandrasa (Jakarta: Erlangga, t.t.), 202.

35 Mahmud, Pendidikan Agama Islam, 150-151. 
yang bermacam-macam di tengah masyarakat yang bermacam-macam pula. Sebagai lembaga terkecil dalam masyarakat, keluarga memegang peran yang sangat luas dalam kehidupan sosial umat manusia. Sesungguhnya dapat dikatakan bahwa keluarga adalah tahap pertama lembaga-lembaga penting sosial, dan dalam tingkat yang sangat tinggi, ia berkaitan erat dengan kelahiran peradaban, transformasi warisan, dan pertumbuhan serta perkembangan umat manusia. Secara keseluruhan, semua tradisi, keyakinan, sopan santun, sifat-sifat individu dan sosial, ditransfer lewat keluarga kepada generasi-generasi berikutnya. ${ }^{36}$

Mengenai hal ini Ki Hajar Dewantara, dalam kutipan Rehani mengatakan ada tiga pilar lingkungan pendidikan yakni:

1. Lingkungan keluarga.

2. Lingkungan sekolah.

3. Lingkungan masyarakat. ${ }^{37}$

Hal ini menjadi menarik karena Ki Hajar Dewanta menempatkan lingkungan keluarga sebagai lingkungan yang pertama dan utama dalam lingkungan pendidikan yang di gagasnya. Nampaknya apa yang di gagas oleh Ki Hajar Dewantara bukanlah tanpa alasan yang kuat, bahkan dalam al-Qur'an juga dijelaskan bahwa keluarga memiliki peranan yang sangat penting dalam membentuk dan membangun akhlak keluarga. Sebagaimana dipertegas dalam QS. Al-Tahrim:

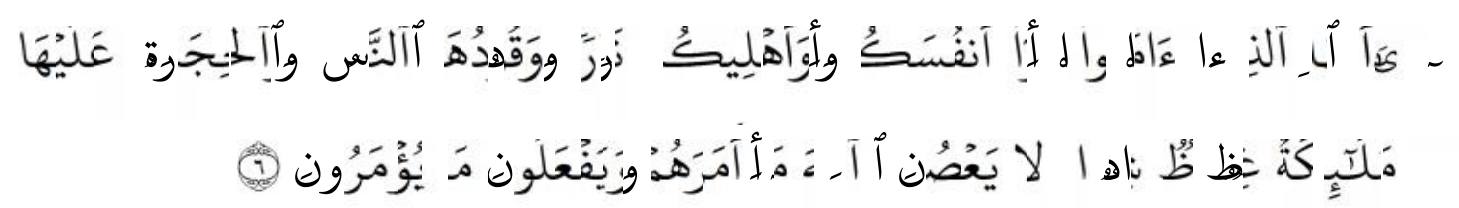

Artinya: "Hai orang-orang yang beriman, peliharalah dirimu dan keluargamu dari api neraka yang bahan bakarnya adalah manusia dan batu; penjaganya malaikat-malaikat yang kasar, keras, dan tidak mendurhakai Allah terhadap apa yang diperintahkan-Nya kepada mereka dan selalu mengerjakan apa yang diperintahkan." (QS. Al-Tahrim $(66): 6^{38}$

\section{Remaja dan Masalahnya}

John W. Santrock, mendefinisikan remaja (adolescence) sebagai "masa perkembangan transisi antara masa anak dan masa dewasa yang mencakup perubahan biologis, kognitif, dan sosio-emosional." ${ }^{\prime 39}$ mengenai rentan usia remaja Santrock mengemukakan, remaja awal dimulai kira-kira 10 sampai 13 tahun dan berakhir antara usia 18 sampai 22 tahun. $^{40}$ Sementara itu, beberapa faktor yang mempengaruhi

\footnotetext{
${ }^{36}$ Ibid., 90.

${ }^{37}$ Rehani, Berawal dari Keluarga, 129. Lihat juga, Zakiah Daradjat, Ilmu Pendidikan, 35.

38 al-Qur'an, 66: 6.

${ }^{39}$ John W. Santrock, Adolescence: Perkembangan Remaja, terj. Shinto et.al. (Jakarta: Erlangga, 2003), 26.

40 Masa remaja awal (early adolescence) kira-kira sama dengan masa sekolah menengah pertama dan mencakup kebanyakan perubahan pubertas. Masa remaja akhir (late adolescence) menunjuk kira-kira
} 
remaja menurut Philip Graham, dalam kutipan Sarlito Wirawan Sarwono membagi faktor yang menyebabkan terjadinya kelainan pada remaja menjadi dua yaitu:

1. Faktor Lingkungan:

2. Faktor Pribadi. ${ }^{41}$

\section{Bentuk-bentuk Kenakalan Remaja}

Mengenai jenis kenakalan remaja yang dikumpulkan oleh pemerintah melalui Bakolak Impres 6/1971 dalam kutipan Sofyan S. Willis, yaitu: 1) pencurian, 2) penipuan, 3) perkelahian,4) perusakan, 5) penganiayaan, 6) perampokan, 7) narkotika, 8) pelanggaran susila, 9) pelanggaran, 10) pembunuhan, dan 11) kejahatan lain. ${ }^{42}$

Sedangkan Sarlito W. Sarwono membagi kenakalan remaja menjadi empat jenis yaitu:

1. Kenakalan yang menimbulkan korban fisik pada orang lain: perkelahian, perkosaan, perampokan, pembunuhan, dan lain-lain.

2. Kenakalan yang menimbulkan korban materi: perusakan, pencurian, pencopetan, pemerasan, dan lain-lain.

3. Kenakalan sosial yang tidak menimbulkan korban di pihak orang lain: pelacuran, penyalahgunaan obat.

4. Kenakalan yang melawan status, misalnya mengingkari status anak sebagai pelajar dengan cara membolos, mengingkari status orang tua dengan cara minggat dari rumah atau membantah perintah mereka, dan sebagainya. ${ }^{43}$

\section{Menanggulangi Kenakalan Remaja}

Menanggulangi kenakalan remaja tidak sama dengan mengobati suatu penyakit. Ini dikarenakan betapa kompleksnya penyebab kenakalan remaja yang terjadi pada setiap anak. Bisa saja perilaku menyimpang atau kenakalan yang dilakukan oleh anak sama, namun belum tentu penyebab anak untuk melakukan tindakan itu sama pula.

Sehubungan dengan tersebut di atas Sofyan S. Willas membagi menjadi tiga cara yaitu, 1) upaya preventif, 2) upaya kuratif, 3) upaya pembinaan. ${ }^{44}$

\section{Memahami Bentuk-bentuk Kenakalan Remaja Di Desa Daun}

Remaja dan masalahnya bukanlah sesuatu yang asing lagi kita dengar. Seakan tidak ada habisnya, berbagai permasalahan kenakalan remaja kian marak diperbincangkan, terutama di era globalisasi dan teknologi sekarang ini. Tentunya ini tak lepas dari berbagai faktor yang mempengaruhi perilaku remaja.

setelah usia 15 tahun. Minat pada karir, pacaran dan eksplorasi identitas sering kali lebih nyata dalam masa remaja akhir ketimbang dalam masa remaja awal. Lihat, John W. Santrock, Adolecence, 26.

${ }^{41}$ Sarlito Wirawan Sarwono, Psikologi Remaja (Jakarta: RajaGrafindo Persada, 2002), 206-207.

42 Sofyan S. Willis, Remaja dan Masalahnya, 91.

${ }^{43}$ Sarlito Wirawan Sarwono, Psikologi Remaja, 256-257.

44 Ibid., 140-144. 
Adapun beberapa bentuk kenakalan yang terjadi di desa Daun antara lain adalah sebagai berikut:

1. Kebut-kebutan di Jalan.

Kebiasaan remaja berkendara dengan kebut-kebutan di jalan sudah menjadi hal yang wajar kita lihat dalam sehari-hari. Tak jarang juga menimbulkan kecelakaan di jalan yang melibatkan sesama pengendara maupun para pejalan kaki. Tidak hanya itu, pengetahuan anak tentang bagaimana cara berkendara yang baik juga mempengaruhi etika anak dalam berkendara di jalan. Karenanya peran serta orang tua menjadi penting, karena sebagai orang tua harusnya tidak hanya memberikan segala fasilitas kepada anak akan tetapi mereka juga berkewajiban untuk memberikan peringatan dan nasehat pada anak untuk dapat menggunakan fasilitas yang diberikannya sebaik mungkin tanpa melakukan sesuatu yang dapat merugikan dirinya dan orang lain.

Tidak hanya itu, aksi ugal-ugalan yang mereka lakukan juga berujung pada aksi balap liar. Tentu hal ini akan merugikan banyak pihak terutama bagi diri si anak yang bersangkutan. Dan aksi ini juga sering kali dijadikan sebagai ajang taruhan antar sesama pembalap liar yang nota beni mereka masih duduk di bangku sekolah.

2. Judi (Sabung Ayam, Santing, Adu Sapi dan Lain-lain)

Agama Islam membolehkan berbagai macam bentuk hiburan dan permainan bagi setiap pemeluknya, tapi Islam melarang setiap permainan yang di dalamnya terdapat unsur perjudian. Perjudian adalah taruhan, suatu bentuk permainan untung-untungan masalah harta benda yang dapat menimbulkan kerugian dan kerusakan pada semua pihak. ${ }^{45}$

Bentuk perjudian ini nampaknya masih dilakukan juga oleh masyarakat di desa Daun khususnya, sebagaimana dalam paparan data di jelaskan di antara bentuk perjudian yang sering kali terjadi adalah pertama sabung ayam dan adu sapi. Sabung ayam dan adu sapi ini seakan sudah menjadi kebiasaan yang biasa dijadikan sebagai salah satu sarana oleh sebagian masyarakat Bawean sebagai ajang untuk silaturahim antar warga dengan warga lainnya. Namun seiring waktu, ini menjadi tercemar oleh ulah sebagian masyarakat yang menjadikan hal tersebut sebagai ajang perjudian untuk meraup untung dengan jalan yang haram. Akhirnya, budaya adu sapi yang telah lama ada di Bawean pun menjadi lahan judi yang sangat menggiurkan bagi para oknum masyarakat tak bertanggung jawab.

Kedua, permainan Santing (dan sejenisnya) walaupun Islam tidak melarang segala bentuk permainan namun jika di dalam permainan tersebut dicampuri dengan unsur-unsur perjudian tetap saja itu tidak di benarkan dalam Islam. Santing adalah sebuah permainan yang banyak di gemari oleh masyarakat di Bawean tak terkecuali di desa Daun. Sebenarnya tidak ada yang salah dengan

${ }^{45}$ M. Abdul Mujieb, et.al, Kamus Istilah Fiqih (Jakarta: Pustaka Firdaus, 1994), 142. 
permainan Santing ini hanya saja ulah sebagian oknum yang menjadikan permainan ini sebagai ajang perjudianlah yang menjadikannya bermasalah.

3. Bermain Perempuan

Seiring berkembangnya zaman pergaulan bebas antar remaja kian menjadi. Ditunjang dengan kemajuan teknologi dan berbagai media sosial seperti Facebook, Twitter, BBM, Instagram dan lain sebaginya yang kian memudahkan individu untuk dapat berhubungan dengan individu lainya. Dengan berbekal rayuan gombalnya mereka mencari para wanita incarannya untuk kemudian dijadikan sebagai pacar. Di dukung dengan adanya berbagai teknologi terutama teknologi informasi seperti handphone (HP) menjadi sarana paling handal untuk mengelabui para orang tua serta untuk menghubungi sang pacar.

Berangkat dari hal tersebut, banyak anak terutama perempuan yang keluar malam bersama pacarnya, atau lebih dikenal dengan wanita buser ${ }^{46}$. Sebagaimana pemaparan Marsugi, banyaknya remaja yang bermain perempuan baik perempuan dari desa setempat ataupun perempuan dari desa lain yang keluar malam bersama pacarnya bahkan kumpul dalam satu rumah tanpa pengawasan dari orang tua. ${ }^{47}$

4. Miras (ngomix)

Di Indonesia minuman beralkohol diawasi peredarannya oleh negara, terutama minuman impor. Jenis minuman beralkohol seperti, anggur, bir brendi, tuak, vodka, wiski dan lain-lain. Sering kita jumpai pemberitaan, baik media cetak maupun media elektronik mengenai dampak negatif dari mengonsumsi minuman keras.

Di era globalisasi sekarang ini, ditunjang dengan berbagai kemajuan baik di bidang ekonomi, pendidikan, sosial dan sarana-prasarana serta dengan adanya pasar bebas kian memudahkan masyarakat global untuk melakukan transaksitransaksi dengan wilayah lain.

Bawean dengan semakin majunya pelayanan rute Bawean-Gresik baik melalui jalur laut maupun udara kian menantang kesiapan masyarakat Bawean secara keseluruhan dan masyarakat Daun khususnya karena dengan demikian tidak bisa dipungkiri di tengah kelengahan para petugas banyak pedagang nakal maupun para pengedar miras yang menyusupkan minuman haram tersebut ke Bawean sehingga menjadi penyakit baru di Bawean khususnya desa Daun.

Seakan tidak pernah kehilangan akal, bagi anak yang sudah kecanduan miras atau hanya sekedar coba-coba atau karena alasan lainnya. Berbagai hal mereka lakukan untuk memenuhi hawa nafsunya terutama bagi remaja yang masih pemula atau sekedar ikut-ikutan temannya. Obat batuk Komix pun jadi solosinya, atau lebih dikenal dengan istilah ngomix. Dengan berbekal pengalaman

${ }^{46}$ Istilah yang digunakan oleh masyarakat setempat untuk menyebut wanita malam.

${ }^{47}$ Marsudi, Pamong Dusun Daun Eleran, Daun Eleran, 19 April 2016. 
dan coba-coba mereka meng oplos obat batuk tersebut kemudian mereka gunakan sebagai bahan untuk bermabuk-mabukan.

Inilah fenomena yang banyak terjadi di Bawean khusnya juga di desa Daun yang banyak melanda para remaja dan anak yang masih di bangku sekolah. Selain praktis, mudah di dapat dan harganya terjangkau hal tersebut menjadi solusi bagi para pecandu miras. Sebagaimana dilansir di Media Bawean masyarakat merasa resah dengan makin maraknya fenomena ngomix yang dilakukan oleh para remaja. ${ }^{48}$ Dan hampir di berbagai tempat terutama yang jauh dari perkampungan banyak di temukan berserakan sampah Komix yang digunakan bahan oplosan ngomix.

5. Pencurian dan Perampokan

Pencurian dan perampokan adalah merupakan tindakan tercela yang dilarang oleh agama. Agama Islam adalah salah satu agama yang melarang keras tindakan pencurian maupun perampokan. Tak heran jika ada sebagian masyarakat yang begitu tidak senang terhadap pencurian, bahkan melebihi kebenciannya terhadap perbuatan zina walaupun keduanya termasuk perbuatan yang dilarang oleh agama. ${ }^{49}$

6. Narkoba dan Sejenisnya

Penyalahgunaan narkotika dan obat-obatan terlarang (narkoba) di Indonesia akhir-akhir ini mengalami peningkatan yang sangat drastis. Hampir setiap hari kita disuguhkan di berbagai media tentang kasus peredaran dan penyalahgunaan narkoba dan sejenisnya bahkan jika kita lihat di media harian BNN penuh dengan berbagai pemberitaan tentang berbagai kasus di belahan nusantara yang menjadi korban barang haram tersebut.

Korban penyalahgunaan narkoba telah meluas sedemikian rupa sehingga melampaui batas-batas strata sosial, umur, jenis kelamin. Merambah tidak hanya perkotaan tetapi merambah sampai pedesaan dan melampaui batas negara yang akibatnya sangat merugikan perorangan, masyarakat, negara, khususnya generasi muda. Bahkan dapat menimbulkan bahaya lebih besar lagi bagi kehidupan dan nilai-nilai budaya bangsa yang pada akhirnya dapat melemahkan ketahanan nasional.

\footnotetext{
48 "Kades Bulu Lanjang Merasa Geram Wilayahnya Jadi Ajang Oplosan Komix", http://www.bawean.net/2014/09/kades-bululanjang-merasa-geram.html, 23 September 2014, diakses tanggal 15 Juni 2016.

${ }^{49} \mathrm{Men}$ begi oreng toa e lastemor reak engak-engakna ghik amaloan andik anak se andik sifat pangecok deri pade mangandung anakna oreng... men mangandung anakna oreng reak. men lalake engakna se bieasa polana jereak. lalake. Mola e pakabin biesana ambu, bbide ken sifat pangecok polana biesana men pangecok reak ekebe sambik toa" (Bagi orang tua di lastimur seakan lebih malu memiliki anak yang suka mencuri dari pada anak yang menghamili perempuan lain... sebab menghamili perempuan bagi anak laki-laki itu seakan hal yang biasa karena biasanya begitu di nikahkan akan berhenti dengan sendirinya, beda halnya dengan kebiasaan mencuri yang biasanya akan terbawa sampai ia menjadi dewasa). Hasil wawancara dengan Muhammad Imran, Pamong Dusun Lastimur, Lastimur, 19 April 2016.
} 
Inilah yang menjadi alasan masyarakat untuk menyatukan visi dan misinya mencegah dan membasmi peredaran narkoba yang kian hari kian meresahkan masyarakat. Bawean sebagai daerah kepulauan juga terkena imbasnya, Bawean yang dulunya aman dari peredaran narkoba dan obat-obatan terlarang lainnya kini mulai menjamur bahkan yang lebih miris para korban sebagian besar adalah mereka para remaja.

Sebagaimana yang lansir oleh Media Bawean, salah satu yang menjadi korbannya adalah masyarakat Daun. ${ }^{50}$ Ini menjadi menarik, karena setahu penulis bahwa masyarakat Daun selama ini terkenal dengan masyarakat yang agamis, termasuk pemudanya selalu kompak mengadakan acara-acara keagamaan, selain itu di desa Daun juga terdapat banyak dai-dai kondang yang biasa ceramah keluar desa khususnya di lingkup Pulau Bawean. Namun demikian, tetap saja masih kecolongan dengan berbagai kasus-kasus kenakalan terutama terkait dengan kasus narkoba.

Dalam penjelasan di atas terlihat betapa pentingnya perhatian orang tua terhadap anak. Karenanya sebagai orang tua jangan sampai mengabaikan perhatian terhadap anak, sehingga anak mereka benar-benar tumbuh dan berkembang menjadi sosok yang baik taat terhadap perinta agama dan menjauhi larangannya. Dalam hal ini perlu ditegaskan bahwa, perhatian terhadap anak tidak harus setiap waktu namun bagaimana dalam waktu yang relatif singkat ditengah kesibukan orang tua dapat dijadikan sebagai momen yang bararti sehingga benar-benar membekas di hati sang anak.

\section{Upaya Keluarga dalam Menanggulangi Kenakalan Remaja di desa Daun}

Remaja dan masalahnya seakan tidak ada ujung akhirnya. Berbagai faktor yang menyebabkan para remaja berperilaku negatif menjadikan para orang tua harus memutar otak agar anak-anak mereka tidak terjerumus dalam perilaku-perilaku negatif.

Ada banyak metode yang dapat dilakukan oleh orang tua untuk menanggulangi kenakalan remaja terutama dalam rumah tangga atau keluarga. Berbagai metode tersebut tentunya akan berjalan dan mendapatkan hasil yang maksimal manakala diterapkan secara tepat dan benar pula.

Secara khusus upaya yang dilakukan oleh keluarga khususnya kedua orang tua yang ada di desa Daun untuk mencegah kenakalan remaja antara lain sebagai berikut: 1. Nasehat 2. Teladan 3. Membatasi waktu bermain anak 4. Musyawarah Keluarga (matojuk) 5. Memarahi dan menghukum

Secara garis besar metode yang digunakan oleh orang tua di Desa Daun sudah baik. Hanya saja menurut hemat penulis, berdasarkan hasil observasi adalah

50 Proses Hukum Pengguna Sabu Dilanjutkan Ke Polres Gresik", http://www.bawean.net/2015/10/proses-hukum-pengguna-sabu-dilanjutkan.html, 13 Oktober 2015, diakses tanggal 14 Mei 2016. 
berbagai metode yang telah telah mereka terapan, sudah berjalan sebagaimana mestinya.

Namun yang menjadi persoalan adalah pertama, apa yang mereka terapkan dan metode yang mereka gunakan kebanyakan hanya mencontoh secara mekanis/mengkopi metode lama yang dulu dianggap berhasil tanpa melakukan modifikasi dan kontekstualisasi dengan kehidupan riil saat ini yang sedang di hadapi oleh anak, sehingga pola-pola lama yang mereka terapkan dalam kehidupan anak sekarang ini kurang begitu efektif. Apalagi yang mereka hadapi adalah remaja yang secara psikologis mereka masih dalam proses pematangan baik dalam proses berfikir maupun dalam berperilaku.

Kedua, orang tua dalam memberikan nasehat pada anak tidak konsisten terhadap apa yang mereka nasehatkan. Katakanlah, ketika orang tua menasehatkan anak untuk berbuat baik sementara mereka sendiri kurang mencerminkan sikap-sikap baik terutama di hadapan anak. Ketiga, pengetahuan kedua orang tua yang tidak berimbang. Dimana seharusnya keduanya saling melengkapi namun karena berbagai faktor hal tersebut justru menjadi sebuah hambatan dalam pendidikan anak di dalam keluarga.

Hal ini menjadi sebuah tantangan baru bagi keluarga terutama kedua orang tua agar mereka terus belajar bagaimana cara menjadi keluarga dan orang tua yang mampu mengantarkan anak-anaknya menjadi manusia yang memiliki integritas dan akhlak yang baik. Untuk itu orang tua harus mampu memperlakukan anak sebagai individu yang berbeda serta memiliki kompetensi yang unik untuk kemudian diperlakukan secara baik dan benar tanpa harus membeda-bedakan.

Oleh karena itu, menurut Hamka, dalam kutipan Samsul Nizar untuk mewujudkan manusia yang ideal adalah merupakan persoalan yang harus diselesaikan bersama. Upaya ini tentunya harus dimulai dari lingkungan keluarga kemudian secara formal lingkungan sekolah dan masyarakat turut berperan aktif dalam pembentukan sosok manusia yang ideal. ${ }^{51}$

Karena itu pendidikan keluarga adalah komponen terpenting bagi terbentuknya sikap dan mental anak agar bisa menjadi anak yang baik, bisa bersosialisasi dan beradaptasi dengan lingkungannya serta memiliki komitmen yang tinggi sehingga anak tidak mudah terombang-ambing oleh lingkungan sekitar.

\section{Penutup}

Bentuk-bentuk kenakalan remaja yang terjadi di desa Daun antara lain sebagai berikut: (a) Kebut-kebutan di jalan (b) Judi (sabung ayam, Santing, adu sapi dan lainlain) (c) Bermain perempuan (d) Miras (ngomix) (e) Pencurian dan perampokan (f) Narkoba dan sejenisnya.

\footnotetext{
51 Samsul Nizar, Memperbincangkan Dinamika Intelektual, XIV.
} 
Berbagai bentuk kenakalan remaja yang terjadi di desa Daun tentunya ada banyak faktor yang mempengaruhinya. Salah satu faktor yang paling dominan dan sangat menentukan adalah faktor pendidikan dalam keluarga. Ditemukan bahwa pendidikan keluarga yang ada di desa Daun masih belum maksimal sehingga dapat menyebabkan terjadinya berbagai kenakalan remaja.

Terdapat dua faktor penyebab tidak maksimalnya pendidikan dalam keluarga yang ada di desa Daun. Pertama, faktor SDM itu sendiri. Artinya para keluarga kurang mengetahui bagaimana cara mendidik anak yang baik yang mengakibatkan mereka acuh tak acuh terhadap anak. Kedua, faktor ekonomi, yang menyebabkan para orang tua banyak bekerja di luar rumah sehingga mereka kehilangan kesempatan untuk mendidik anak. Terlebih masyarakat Bawean adalah masyarakat kepulauan yang notabene mereka bekerja sebagai petani dan nelayan.

Upaya pendidikan keluarga dalam menanggulangi kenakalan remaja di desa Daun antara lain: (a) Memberi nasehat (b) Memberi teladan (c) Membatasi waktu bermain anak (d) Musyawarah keluarga (Matojuk) (e) Memarahi atau menghukum.

Beberapa upaya tersebut tidak bisa berjalan dengan maksimal karena disebabkan beberapa faktor antara lain:

Pertama, dalam menerapkan metode kebanyakan orang tua hanya mencontoh secara mekanis/mengcopy metode lama yang dulu dianggap berhasil tanpa melakukan modifikasi dan kontekstualisasi dengan kehidupan riil saat ini yang sedang di hadapi oleh anak, sehingga pola-pola lama yang mereka terapkan dalam kehidupan anak sekarang ini kurang begitu efektif. Apalagi yang mereka hadapi adalah remaja yang secara psikologis mereka masih dalam proses pematangan baik dalam proses berfikir maupun dalam berperilaku.

Kedua, ketidakkonsistenan keluarga. Katakanlah, ketika orang tua menasehatkan anak untuk berbuat baik sementara mereka sendiri tidak mencerminkan sikap-sikap baik terutama di hadapan anak.

Ketiga, pengetahuan kedua orang tua yang tidak berimbang atau faktor SDM. Dimana seharusnya keduanya saling melengkapi namun karena berbagai faktor hal tersebut justru menjadi sebuah hambatan dalam pendidikan anak di dalam keluarga.

\section{Daftar Pustaka}

Achmadi, Ideologi Pendidikan Islam Paradigma Humanisme Teosentris (Yogyakarta: Pustaka Pelajar, 2005)

Ahid, Nur, Pendidikan Keluarga dalam Perspektif Islam (Yogyakarta: Pustaka Pelajar, 2010)

Amirulloh, Teori Pendidikan; Karakter Remaja Dalam Keluarga, (Bandung: Alfabet, 2015)

Anwar, Ali, Pembaruan Pendidikan Di Pesantren Lirboyo Kediri (Yogyakarta: Pustaka Pelajar, 2011)

Damopoli, Moljono, Pesantren Modern IMMIM Pencetak Muslim Modern (Jakarta: Rajagrafindo Persada, 2011) 
Daradjat, Zakiah, et.al., Ilmu Pendidikan Islam (Jakarta: Bumi Aksara, 1996)

-------, Pendidikan Islam dalam Keluarga dan Sekolah (Jakarta: Ruhama, 1995)

Hurlock, Elizabeth B., Perkembangan Anak terj. Med. Meitasari Tjandrasa (Jakarta: Erlangga, t.t.)

Illich, Ivan, Bebaskan Masyarakat dari Belenggu Sekolah. Terj. Sonny Keraf (Jakarta: Yayasan Obor Indonesia, 2000)

Luthfiah, Zeni, et.al., Pendidikan Agama Islam Pendidikan Karakter Berbasis Agama Islam (Surakarta: Yuma Pustaka, 2011)

Madjid, Nurcholis, Masyarakat Religius (Jakarta, Paramadina, 2000)

Mahmud, et.al, Pendidikan Agama Islam dalam Keluarga: Sebuah Panduan Lengkap bagi Para Guru, Orang tua dan Calon (Jakarta: Akademia Permata, 2013)

Mubarok, Achmad, Psikologi Keluarga: Dari Keluarga Sakinah Hingga Keluarga Bangsa (Jakarta: Wahana Aksara Prima, 2009)

Mujieb, M. Abdul, et.al, Kamus Istilah Fiqih (Jakarta: Pustaka Firdaus, 1994)

Nizar, Samsul, Memperbincangkan Dinamika Intelektual dan Pemikiran Hamka Tentang Pendidikan Islam (Jakarta: Kencana, 2008)

Rehani, Berawal dari Keluarga: Revolusi Belajar Cara al-Qur'an (Jakarta: Hikmah, 2003), XI.

Salim, Moh. Haitami, Pendidikan Agama dalam Keluarga: Revitalisasi Peran Keluarga dalam Membangun Generasi Bangsa yang Berkarakter (Jogjakarta: Ar-Ruzz Media, 2013)

Santrock, John W., Adolescence: Perkembangan Remaja, terj. Shinto et.al. (Jakarta: Erlangga, 2003)

Sarwono, Sarlito Wirawan, Psikologi Remaja (Jakarta: RajaGrafindo Persada, 2002)

Sri Lestari, Psikologi Keluarga: Penanaman Nilai dan Penanganan Konflik Dalam Keluaarga (Jakarta: Kencana, 2014),

Tafsir, Ahmad, Ilmu Pendidikan Islam (Bandung: Remaja Rosdakarya, 2012)

Tim Penyusun Kamus, Kamus Besar Bahasa Indonesia, Edisi Keempat (Jakarta: Gramedia, 2000)

Undang-Undang Sisdiknas Sistem Pendidikan Nasional (t.t.: Permata Pres, t.t. )

Willis, Sofyan S., Remaja dan Masalabnya: Mengupas Berbagai Bentuk Kenakalan Remaja, Narkotika, Sex, dan Pemecahannya (Bandung: Alfabeta, 2012)

Wiyani, Novan Ardy \& Barnawi, Ilmu Pendidikan Islam: Rancang Bangun Konsep Pendidikan Monokotomik-Holistik (Jogjakarta: Ar-Ruz Media, 2012)

Yusuf, Qadar Muhammad, Tafsir Tarbawi (Pekanbaru: Zanafa Publishing, 2011)

Proses Hukum Pengguna Sabu Dilanjutkan Ke Polres Gresik", http://www.bawean.net/2015/10/proses-hukum-pengguna-sabudilanjutkan.html, 13 Oktober 2015, diakses tanggal 14 Mei 2016.

"Kades Bulu Lanjang Merasa Geram Wilayahnya Jadi Ajang Oplosan Komix", http://www.bawean.net/2014/09/kades-bululanjang-merasa-geram.html, 23 September 2014, diakses tanggal 15 Juni 2016.

“Tidak Hanya Dipaksa Hubungan Intim hingga 25 Kali, Bunga juga Diperas", http://www.bawean.net/2016/02/tidak-hanya-dipaksa-hubunganintim.html, diakses tanggal 11 Februari 2016.

Wawancara dengan Muhammad Imran, Pamong Dusun Lastimur, Lastimur, 19 April 2016.

Wawancara dengan Marsudi, Pamong Dusun Daun Eleran, Daun Eleran, 19 April 2016. 